\title{
Sanrachna
}

\section{Poultry Prices Skid in India Due to Fake News Circulation on Coronavirus}

\begin{abstract}
India had its first case of COVID- 19 on January $30^{\text {th }}$ 2020. Slowly the numbers started to increase by mid of February and so is the information on poultry products. Till January 2020 the prices of poultry products were 147.65 rupees per kg until there was a sharp drop in March 2020. The reason behind it was the rumours that coronavirus is caused by the consumption of poultry products. This paper tries to point to out that how these rumours have badly affected the poultry prices in India by looking at a source on which the information is passed on and also the condition under which people tend to believe such rumours. The study emphasis on the fact that such rumours have affected the business of rural population, in particular, making them sell their products at a lower price.
\end{abstract}

Keywords- Fake news, poultry prices, COVID-19, pandemic, social media, panic state

\section{Introduction}

With more than 2.5 million cases worldwide till $20^{\text {th }}$ April 2020, coronavirus pandemic (COVID-19) has brought a disruption in human life. Leaders from all around the globe became reluctant to accept the situation as a state of emergency. The situation is not new to human species, there has been a history of pandemic diseases like 1918 H1N1, 2002 SARS. But this time the disease was spreading across highly technologically advanced countries, where people are virtually connected through a small device in their pocket. The ultimate requirement of social distancing for prevention from the disease made people more inclined towards a device called mobile phones. In order to kill boredom, people became more reliant on maintaining connectivity through social media like Facebook, Twitter, WhatsApp and Instagram. These platforms over a while became a source for sharing information. Thus, people started sharing information about the virus. What shows here, that social platforms have a very strong foundation where people have effective responses towards COVID-19. It showcases not only information but also challenges being created by the diseases. Through this, we learn about how various people could respond to such challenges like government officials, healthcare people, service providers and social network companies (Limaye, Sauer, Ali, Bernstein, Wahl, Brian and Barnhill, 2020).

Nevertheless, the actors also have a vital role to play in preventing social media from being a tool of distrust and false information; creating a threat to public health. Rumours travel faster than any disease. Information can spread from a word of mouth or through a prank on social media. Later it takes a form of misinformation and this information changes every time as it passes from one mode to another. The concept of legitimacy has a different hold on the social media platform. Users have trusted people in their network who support their content and exchange or forward information as a valued source of information. The more it is 


\section{Sanrachna}

disseminated, the more it is perceived as legitimate information. However, this form of sharing contrasts with the normal mode of exchange of information which is specialised and have verified knowledge about it. Thus, people have disseminated information on COVID-19 from precautions to how it spreads. This has led to the formulation of information that people want to believe.

In India, the information made people believe that the inception of COVID -19 is linked with the consumption of poultry products. The outbreak of the virus started in December 2019, but the sale of poultry products started to decrease by mid-February. Despite being a vegetarian country India is projected as one of the largest consuming countries of chicken, meat and mutton. According to, Sample Registration System (SRS) survey released by the registrar general of India in 2014, showed that around $71 \%$ of people in India are non-vegetarian (Rowland, 2017). With a sudden pandemic crises, people have shifted their focus from nonvegetarian to vegetarian food; but long after it came into being. This drastic shift has made this paper to argue that what made people focus only on food consumption when medication and sanitation should be the first priority? Why the effect on poultry prices showed a slop in February when the virus started spreading from December? On what grounds people believe such information? Which platform has a major role in disseminating such information? This essay tries to answer all these questions in the context of India while comparing it with the countries which have been badly hit by the virus.

\section{Objective}

The paper will look at a crash of poultry prices from 2019 till 2020. Its impact on food distribution and change in food consumption pattern among people in India after lockdown. Lastly, the role and impact of social media platforms of the poultry market.

\section{Overview on Poultry business in India}

In 2016 Indian poultry business was valued around Rs 80,000 crore and organized commercial business sector account for $80 \%$ of total market share while the rest account for unorganised sector according to National Action Plan for Egg and Poultry 2022. It was estimated that poultry population of 729 million small and medium farmers are engaged in contract farmers while the 30 million are indulged in backyard farming. The reason for discussing the value of poultry business is because the population of poultry consumption is increasing exponentially even in the country like India. The proportion vegetarian countries are very low except India (29\%), Israel (13\%), Australia (2-11.2\%), Sweden (10\%) and Italy (7- 10\%) (Choudhary et al, 2017 , p.251). Through this, one can estimate that the major population is consuming nonvegetarian food. In India, globalisation had a major impact on food consumption pattern. As mentioned before $71 \%$ of people consume poultry products in India and the number is still increasing.

According to, National Council of Applied Economic Research, New Delhi the rice consumption in the rural household has declined from $83 \mathrm{~kg}$ to $73 \mathrm{~kg}$ in 2010 ; and in the urban 


\section{Sanrachna}

household, it has declined from $64 \mathrm{~kg}$ to $55 \mathrm{~kg}$ in 2010 . Whereas the egg production in the country has increased from 83 billion in 2016 to 88 billion in 2017. "According to data from the central government's sample registration system baseline survey (SRSBS) (2014), Telangana tops the list of 21 big states in the country in non-vegetarianism $(98.8 \%$ men and 98.6\% women) followed by West Bengal (98.7\% men and 98.4\% women) and Andhra Pradesh (98.4\% men and $98.1 \%$ women). These two states (Andhra Pradesh and Telangana) are also the largest producers of egg and meat" (Choudhary et al, 2017, p.252).

\section{Poultry and pandemic}

With witnessing an increasing trend in the poultry business in India, the market also faces certain challenges like feed costs, transportation, infrastructure, inadequate cold storage warehouses and most importantly its vulnerability to diseases, affecting the prices and the production in the business. Every year country reports erratic instances of bird flu, and the authorities spread the word while taking fast action in controlling the infection. Thus, such outbreaks are limited and are easily controlled by the poultry market. According to Indian Council of Food and Agriculture, poultry production continues to "focus on improving production through better Feed Conversion Ratio (FCR) by testing with feed mixes, lower mortality rates through superior farm management, and constant efforts to improve other parameters like hatchability, average daily weight gain and reducing selection gap" (Indian Council of Food and Agriculture, p.3).

The above discussion emphasis on the fact that government are well aware of any disease and take best of possible action to control it. In addition, they spread awareness regarding the source of the disease. The similar step was taken by the government of India with an outbreak pandemic disease known as coronavirus. With the immediate lockdown on 24/03/2020, the government mentioned of how the disease is spread and to prevent it. COVID-19 as per WHO guidelines can spread through saliva or a droplet discharged from the nose while sneezing or coughing as it is a respiratory disease. Since then the virus outbreak in many countries at a very fast pace. There are three levels at which this virus is spread: at first level, the virus is spread through the infected person who has travel history, at the second level the virus spread through local transmission and at third level, there is a community spread. In most of the countries, the COVID-19 spread through a person who has travel history and, in some cases, these people are also proved to be a super spreader.

Furthermore, coronavirus is termed as a group of viruses that have many types. In recent times, two outbreaks have emerged from coronavirus: Severe Acute Respiratory Syndrome (SARS) and Middle East Respiratory Syndrome (MERS) in 2003 and 2012 respectively. Thus, the pandemic itself is not a new concept. However, this time in India the pandemic gets to associated with a food consumption especially poultry products due to rumours surrounding poultry business.

\section{Impact on Poultry Prices with the outbreak of COVID-19}




\section{Sanrachna}

Poultry products headed for its crisis after the outbreak of COVID-19 in India. India's weekly sale has plummeted to $47 \%$ while the drop in prices has slumped around $60 \%$ according to B.S Yadav, managing director of Godrej Agrovet Ltd, one of the leading companies in the poultry industry. Farmers having a loss of Rs 100- 130 on every bird (Bloomberg, 2020). Farmgate prices have fallen to Rs $15-35 \mathrm{~kg}$ against the production cost of Rs $80-85$ per $\mathrm{kg}$. thus, poultry producers started cutting down on production to cope with losses (The Hindu, 2020). This loss was incurred due to the spread of misinformation that COVID-19 is caused by the consumption of poultry products.

Table 1 Poultry Monthly Prices in India Rupees by Per Kilogram and Change in Production Cost

\begin{tabular}{|l|l|l|}
\hline MONTH & PRICE & CHANGE \\
\hline November 2019 & 132.14 & $0.53 \%$ \\
\hline December 2019 & 140.95 & $6.67 \%$ \\
\hline January 2020 & 147.65 & $4.75 \%$ \\
\hline February 2020 & 134.32 & $-9.02 \%$ \\
\hline March 2020 & 133.77 & $-0.41 \%$ \\
\hline
\end{tabular}

The above-mentioned table shows how after January poultry business witnessed a sharp drop in prices. This time was a period when the number of coronavirus cases surging up.

Egg producers alone lost Rs 600 crore by the mid of February, selling it at a price of Rs 2.50 against the production cost of Rs 4 . As mentioned earlier poultry business accounts for million of farmers employing over 2.75 crore people in India. Are now looking a rescue from this unforeseen circumstance as this has been the supplementary income for the generation to farmers and nutrition for the poorest of the poor (Dahd, 2020, p.1).

In amidst this chaos, it is the small farmers who been the victim of such fake rumours. As stated in the starting of this paper, southern states are poultry hub in India and hence they are largely affected by this rumour. As cases spread in southern India, people stop eating meat because of the rumour. In Hyderabad and Rangareddy, where most of the poultry produces in Telangana, the active COVID-19 cases are 400 and 16 respectively by 27 April 2020 (Government of Telangana, 2020). In Namakkal district of Tamil Nadu, the COVID-19 case is 61 by 28 April 2020, despite no relation has been found between consumption of poultry products and COVID-19 transmission, people begin to fears to consume poultry products even when the cases of COVID-19 is not as high in poultry hub of India, this has a huge impact on people related to the poultry industry (Government of Tamil Nadu, 2020). "In Namakkal, India's principal poultry hub, about 200 million chicken eggs lie unneeded. As a result, the livelihoods of the nearly 20 million people dependent on the national poultry industry have been severely and adversely hit" (The Wire, 2020). In addition, to this India produces third-highest amount of egg and the seventh-highest amount of chicken and meat among the world. The recent 


\section{Sanrachna}

disruption in supply and demand chain because of the rumours have badly affected the lives of many.

It is of extreme importance to look at a condition under which such rumours started circulating but firstly, it is crucial for this essay to understand that under what mindset people are to formulate and to believe such information.

\section{Coronavirus set on Panic State}

Panic Disorder is a basic human anxiety syndrome. It is an emotion found not only among humans but also among all animals. Panic experiences stress, fear or terror. It occurs due to physiological and psychological condition set on an organism. Anxiety can vary from small, flashy event to constant all-day fear. In other words, it's a mental and behavioural response to any threat or danger. It is stated by all the researcher that anxiety is related to fight/ flight response as the sole motive of anxiety to fight and flee the danger. It is estimated that the condition of anxiety or panic disorder has a 2-month prevalence of $1-2 \%$ and a lifetime prevalence of $4 \%$ or greater (Goddard, 2017, p.1). it is linked with extreme suicidality condition. On a physical system, it has Nervous and Chemical effects, Cardiovascular effects, Respiratory effects and Sweat Gland effects.

Respiratory Effects in particular as we are looking at it from the point of view COVID- 19. The fight/ flight response is associated with an increase in the speed of breathing as the defence organism (parasympathetic nervous system) requires more oxygen to prepare itself for the action towards driving away from the anxiety; therefore, tissues need more oxygen for it. However, such deep breathing results in breathlessness, choking and sometimes tightness in the chest. And if no action occurs then such breathing can decrease the blood supply to the head. All of this occurs in small proportion therefore it is not dangerous but can cause blurred vision, dizziness and confusion.

In addition to this, Supreme court on $31^{\text {st }}$ march 2020 asked Centre to counsel migrants and help them to understand the situation on the country's lockdown who are on the roads to return to their villages. They are in the panic state due to sudden news of coronavirus lockdown. Indian express stated that (Indian Express, 2020):

The SC bench, also comprising Justice L Nageswara Rao, is hearing two separate PILs filed by Advocates Alakh Alok Srivastava and Rashmi Bansal on the exodus of migrants. On Monday, the SC observed that the migration of labourers out of panic and fear was becoming a bigger problem than the coronavirus.

In 2009, Director-General of WHO, Margaret Chan said the very term pandemic trigger global panic. It is not a matter of how a disease is spread but how it is perceived. Pandemic and epidemic term is unfettered to deadly disease but also have a psychological and emotional impact. But panic disseminates at a much higher pace than real information. Some diseases cause moral panics like HIV/ AIDS or the outbreak of severe acute respiratory syndrome (SARS) in 2003. In inception when it occurred in Southern China it was called severe acute nervousness syndrome because it was accompanied by fear making it a moral panic. However, 


\section{Sanrachna}

the illness and the sense of its risk and our response to that risk shape the experience with that illness (Gilman, 2010). Furthermore, the source of information also reflects and generate panic for example, “Arunachal Pradesh officer commits suicide' COVID-19 related stress could be trigger" (Hindustan Times, 5/04/2020). People with flu starts researching coronavirus and start assuming that they soon going to die which is reasonable looking at an above-stated example. However, people do not look at information from its source, the panic mode makes them believe whatever they hear or see related to pandemic disease. This where the formulation of fake news begins.

\section{The role of fake news in a time of the pandemic}

UNESCO work on strengthening of education on journalism as they focus on International Programme Development of Communication (IPDC). It is to teach and share of journalism from a global perspective that deals with the emerging problem of disinformation that confronts society in general and journalism in particular. UNESCO consider 'news' is information which is verified in the public interest and therefore, fake news undermines the credibility of information and does not fulfil the gap of verification. It can be in a form of text messages, social media, videos or visual memes. The problem with the spread of fake news that it is well organised, resourced and reinforced by automated technology. Fake news also consists of certain information which is not phoney, thus, making it difficult to make a distinction between real news and fake news. Fake news can affect policies, public officials, even democracy itself.

In addition to this, "In November 2018, representatives from eight countries joined the United Kingdom's Digital, Culture, Media and Sport Committee for a meeting known as an "International Grand Committee" (IGC), to discuss the spread of disinformation, the threat of fake news, questions of privacy and protecting individuals' data" (CIGI, 2019). Its first meeting was regarding Cambridge Analytica Scandal, of how personal data is being shared via Facebook apps. It also included Google, Twitter and WhatsApp like social media platforms which are dominating the whole world. Dealing with online information which disseminates false news can obstruct people politically all around the world. Thus, the committee recommended filtering the information which is politically targeted containing false information. Particularly, in India, fake news is drivers for violence. The main source of disinformation is WhatsApp, the Facebook-owned encrypted messaging platform. Killing over crime is sometimes shown as mob lynching which largely blames the WhatsApp raising the question on people's security and privacy. India's struggle with WhatsApp further becomes complicated when there is a shift in the nation's approach to Foreign Technology companies. Government is seeking restrictions technological giants like amazon, google, twitter for safeguarding the information. Government has also asked IT ministry to store certain data physically in India. According to the data provided by Wired, it points out that (The Wire, 2020):

The small, bright green WhatsApp icon is ubiquitous on India's hundreds of millions of smartphones. The platform has transformed daily life here for its users, which the company says exceed 200 million —its largest market.... But in markets like India, as 


\section{Sanrachna}

well as Brazil and Mexico, WhatsApp was already a dominant player in messaging. The app's simple, clutter-free design made it easy to use, even for people picking up a phone for the first time. In parts of rural India, where connectivity is limited and where websites struggle to load, the app can often function without issue.

It is more than sending a message to person to person. It is used by political parties to harvest information, used by shopkeepers to sell goods and by magazines to spread the news. Cheap smartphones and reasonable internet packages handed the app to the people coming online for the first time. These people are vulnerable to fake news and disinformation. This further influence person into group thinking of information which further moves people into the act of violence. Sometimes the information is not fake however, the place where information is relevant to differ. Like the information children being kidnapped by a group of goons resulted in a massacre in the village of Rainpada in Maharashtra. The belief started from the WhatsApp image where children were lying dead on the ground half covered in sheets. The image was of children who were killed in Syria during a chemical attack. This information was passed on from an open network that is, a community was convinced by the visual news that a gang kidnap the child and harvest their organs.

\section{Journalism could be another source of fake news}

Another formulation of fake news could be through journalism. This could be because of weak journalism that is, a knowledge comprises of poor research or carelessness in verification. As a common source of information is social media, journalism plays a vital role in it. In journalism, it is not about grasping false information but they tend to disbelief all the information whether the information is real or not. This is could be understood by looking at the existing crisis: coronavirus with which whole is affected.

\section{The Start of a Rumour}

Social media plays a very important role in spreading the news about COVID-19. Normally, fake news does not surround near health system in India but it has surged up in the last few months after battling with the pandemic disease known as COVID-19. Here are some examples like one message said that there is advisory audio by UNICEF asking people to avoid icecreams and cold beverages and wash your clothes regularly because the virus can stay for 9 hours on a fabric. Another message recommended intake of heavy Vitamin C. Another there was a rumoured video which showed that men being shot in China and lying on streets; showing the fear of coronavirus.

As these videos become viral, it shows that Indian with coronavirus fear is also looking for answers and searching on YouTube and other social media accounts. One such popular video comes from the area $270 \mathrm{~km}$ far from New Delhi. 'In Bareilly with a population of nearly one million, a team of people is circulating viral videos on the spread of the virus, with healthy doses of unverified information and conspiracy theories.' Prajapati news, a YouTube channel with around 6.21 million of subscribers put on videos and information with eye-catching 


\section{Sanrachna}

headlines. One such video claimed that coronavirus is spreading because of non-vegetarian food. Prime Minister Narendra Modi has requested people on not rely on fake rumours regarding coronavirus. Government has also asked giant social media platforms to control the spread of misinformation. But again, the problem is that the companies are working on removing fake news rather than promoting authentic content.

In India, WhatsApp is one of the strongest social media platforms. India is the largest market of Facebook-owned application WhatsApp. It is used by more than 400 million users. The reach of WhatsApp in India is growing at a very rapid pace in recent years as shown by the below figure it increases by 10 times from 20 million in August 2013 to 200 million in February 2017. Among all social networks in India, after YouTube and Facebook, WhatsApp is the third most active social networks used by internet users and in terms of the messenger, WhatsApp ranks topmost used app.

\section{What makes people spread fake news?}

Sociologist and social psychologist have put a light on rumours as circulation of misinformation can be considered as conspiracy theories. This focus particularly on the individual. This raises a question of why individual tend to believe on such unlikely news? What makes them dispose of such gullibility? Who is affected most by it? Firstly, this could be understood as a part of the social system of interacting persons. It gives a theory that news is communicated or shared among the people who are in any sort of relationship and later, it starts growing from group to group. In other words, from the close end network, it becomes part of an open-end network system (Difonzo, 2018). People who believe rumours are often rational, in a sense that their belief is partially sensible in the realm of existing knowledge. Therefore, it is important to understand that a rumour would not spread until it is partly true.

Its other side can be explained in a way that rumours also spread through overlapping processes that is, social cascades and group polarization. Social cascades occur because individual rely on information what other tends to believe. If the majority believes a rumour then we as an individual started inclining towards that rumour. Thus, our partial knowledge makes us rely on rumour. In addition, rumours trigger strong emotion in us, like fear, threat or anxiety, which further helps in spreading of rumour and create a panic state among people. Secondly, group polarization occurs when like-minded people get together and start thinking an extreme version of what they used to think before. After talking to each other and sharing their extreme version of knowledge; from being tentative they become certain about that rumour and believe that rumour as true information. Thus, their knowledge is being distorted due to their subjective views (Sunstein, 2009).

\section{Unveiling the Truth behind Rumors}

It is important to make clear the basic understanding of COVID-19 that it is a respiratory infection which spreads through droplets transmitted in the air. No study or news has stated or has been proved that virus can stay or is a source of this pandemic disease. People tend to 


\section{Sanrachna}

believe such false rumour because their understanding starts from the information that the virus originated from the poultry market in Wuhan, China; which is true. Secondly, this virus is also found among animals and birds like bats; which is also true but there is no certain evidence that proves that it has spread from birds to humans.

However, but the virus did not originate from poultry products. Dr Laxman Jessani, Consultant, Infectious Diseases, Apollo Hospitals, Navi Mumbai stated that no food is entirely unsafe for consumption. He further added (Times of India, 2020):

"The SARS- CoV-2 virus is usually transmitted through direct contact with an infected person's body fluids like from coughing or sneezing or indirectly through contact with surfaces. Coronaviruses need a host and cannot grow in food. "As far as food is concerned, there is currently no evidence that food can be a route of transmission of the virus or a determinant of any form of infection. So, eating non-vegetarian food is perfectly safe".

In addition to this, no evidence or statement is supported by WHO which says that virus is transmitted through poultry products. Maintaining hygiene and cross-checking sanitation practices can cut down the risk of being getting infected. If people are careful about touching items and maintaining hygiene as instructed by the government like washing hands regularly then the virus can be avoided. Same goes for any food whether vegetarian or non-vegetarian food. If a virus to survive on edible products then it could be any food and therefore it is important to ensure that any food goes through a cleaning process before it is cooked.

The above stated partial information makes people believe that coronavirus is more likely to spread via poultry products. Now imagine in the world where the information is one click away. Sources like Wikipedia and WhatsApp act as a primary source of information for people who are looking for coronavirus under a panic condition. Rumours are expected to spread at a much higher rate through these social media because of the real-time nature of these media.

However, in India, the bird flu also caused fear of consuming the chicken. In January 2020, the highly contagious H5N1 bird flu outbreak in Chhattisgarh also become the reason for fear among people. Along with the rumours, this bird flu also creates panic among poultry buyers and make the poultry industry losses. The outbreak of bird flu in some part of Kerala and Karnataka also make it difficult for poultry farmers in Tamil Nadu. More than 10 crore eggs are lying at various poultry as there is no one to buy them, as per National EGG Coordination Committee chairman. They claimed that INR 10 crore is being lost every day as eggs remain unsold. According to them, there are guidelines to prevent the bird flu outbreak but with coronavirus, such rumours lead to losses for manufacturers. The President of Tamil Nadu Poultry Farmers' Association estimated that the poultry industry has lost nearly INR 800 crore since January (Deccan Herald).

\section{Action Taken for Building Trust}

Our knowledge about COVID-19 is continuously evolving. Therefore, the government have collaborated with social media companies asking them to stop such rumours. Though they have 


\section{Sanrachna}

been successful in removing such false rumours but are unable to stop from formulating. In addition, the Telangana Government ate chicken at a public event in order to refute the rumours around poultry products and have appealed the public to do the same (Livemint, 2020). Also, The Food Safety and Standards Authority of India (FSSAI) chief executive officer G S G Ayyangar at Assocham event said that "Lot of misconception is there that coronavirus will spread through chicken and mutton, there is nothing like that. It is scientifically not proven, I am a scientist, I will not buy that argument," (FSSAI, 2020). This show that the government is taking initiative on its behalf. As per the announcement of lockdown Food Corporation of India sent enough stock to all the states in order to implement PM Garib Kalyan Ann Yojana (PMGKAY). They have delivered an average of 1.44 Lakh MT food grain per day. This is to provide $5 \mathrm{~kg}$ of cereal per person for a month. However, the public distribution system was supposed to cover $75 \%$ of the rural population and $50 \%$ of urban population and this number varies from state to state. On average, 922 million people were eligible for PDS in 2020. But Center used the data of 2011 and the population has increased since then. Therefore, the quantity of food has also increased. But this problem is burdened with the people who have shown a drastic shift from non-vegetarian food. Scholars Meghana Mungikar, Jean Drèze and Reetika Khera pointed out that due to population shift from non-vegetarian food to vegetarian food the distribution was only able to cover $60 \%$ of the population eligible for public distribution system (The wire, 2020). This has put into another state of emergency. Therefore, it is extremely important to verify the information and double-check before sharing it in our peer network.

\section{Conclusion}

In conclusion, one can say that at this point it is difficult to draw a deduction that coronavirus is spreading through poultry products as there is no evidence to prove henceforth. If one argues that it has spread through bats, still it does not rationalize the fact that poultry products have any role to play in it. We can look into the countries who are completely based on nonvegetarian food like Japan, South Korea, European countries and so on. Furthermore, coronavirus does not denote single virus it stands for a group of related viruses, such as SARS$\mathrm{CoV}-2$, the MERS CoV, bovine coronaviruses, avian coronaviruses and others; which transmits from an infected human to another who is coughing or sneezing. The circulation of fake news comprises of partial true information which ultimately makes a person believe information under the existing crisis. One should also not forget that rumours trigger panic symptom like fear which makes person over sympathized with the situation and encourage them to pass on the information to people in their close relation without further checking its source. However, in the end, the initiation of this virus is still unknown despite various tests. This shows that likeminded people imagine a situation to a different extent making them jump to a conclusion. With this global crisis, India is a country where poultry business has been badly costing at a life of many people, and turning towards other options in foods. Making people believe that virus is contained on poultry products. However, infected people have not been classified under vegetarian or non- vegetarians in India yet. So, there is no proof that the virus infects those people who consume poultry products. 


\section{Sanrachna}

\section{References}

Anon,

2020 ,

Accessed

from:

https://www.indexmundi.com/commodities/?commodity=chicken\&months $=120 \&$ currency $=\mathrm{i}$ $\underline{\text { nr }}$

Anon, 2020/03/31. Panic will Destroy More Lives than Virus: SC tells Center to counsel migrants, Indian Express, from https://indianexpress.com/article/coronavirus/supreme-court-coronavirus-migrants-6340178/

Choudhary et al and Kumar, N. 2017, Environmental Impact of Non- Vegetarian Diet: An Overview, International Journal of Engineering Sciences and Research Technology, 6(8), pp.251-257.

Difonzo, Nickolas. 2018, Conspiracy Rumor Psychology, Rochester Institute of Technology, pp. 257- 268.

Democracy, Emerging Technology, Internet Governance. 2019, Centre for International Governance Innovation. Timeline: The International Grand Committee on Disinformation and "Fake News". Accessed from: https://www.cigionline.org/igc

FSSAI. (05/03/2020), No Scientific Data to Prove Non-Veg, Including Poultry, Seafood Responsible for Coronavirus, Times of India accessed from: https://fssai.gov.in/upload/media/FSSAI News Data TOI 0603 2020.pdf

Gilman, Sander L. 2010, Moral Panic and Pandemics, The Lancet, Vol 375(9729), Retrieved from: https://www.thelancet.com/journals/lancet/article/PIIS0140-6736(10)60862-8/fulltext

GOVERNMENT OF INDIA, Indian Council of Food and Agriculture, Indian Poultry Market Overview, $\quad$ pp1-5 Accessed from: https://www.icfa.org.in/assets/doc/reports/Indian Poultry Market Overview.pdf

GOVERNMENT OF INDIA, Department of Animal Husbandry, Dairying \& Fisheries Ministry of Agriculture \& Farmers Welfare, National Action Plan for Egg \& Poultry-2022 For Doubling Farmers' Income by 2022, pp.1-37 Accessed from http://www.dahd.nic.in/sites/default/filess/Seeking\%20Comments\%20on\%20National\%20Ac tion\%20Plan-\%20Poultry-\%202022\%20by\%2012-12-2017.pdf

GOVERNMENT OF TAMIL NADU, 2020, Health \& Family Welfare Department, Accessed from:

https://nhmtn.maps.arcgis.com/apps/opsdashboard/index.html\#/095ad0a1c0254b058fa36b32d1ab $\underline{1977}$

GOVERNMENT OF TELANGANA, 2020, Indian Institute of Health \& Family Welfare, Accessed from: https://covid19.telangana.gov.in/district-wise-cases/

Ireton, Cherilyn and Posetti, Julie. 2018, Journalism, 'Fake News' \& Disinformation, UNESCO Series on Journalism Education, Accessed from: 


\section{Sanrachna}

https://en.unesco.org/sites/default/files/journalism_fake_news_disinformation_print_friendly _.

Jayant Limaye, Rupali; Sauer, Molly; Ali, Joseph; Bernstein, Justin; Wahl, Brian and Barnhill, Anne. 21/04/2020, Building trust while influencing online COVID-19 content in the social media world, The Lancet, Accessed from https://www.thelancet.com/journals/landig/article/PIIS2589-7500(20)30084-4/fulltext

Kulkarni, Vishwanath; Kurmanath, KV and Kumar, Sanjeev. 10/03/2020. Now, Poultry Industry 'Catches' Covid-19, The Hindu Accessed from: https://www.thehindubusinessline.com/economy/agri-business/poultry-industry-seeksbailout-as-prices-crash-amid-covid-19-fears/article31021906.ece\#

Khandekar, Omkar. (21/03/2020), How WhatsApp forwards on coronavirus broke the ₹1 Tn Indian poultry industry, Livemint Accessed from https://www.livemint.com/mintlounge/features/how-whatsapp-forwards-on-coronavirus-broke-the-1-7-bn-indian-poultry-industry11584715653782.html

McLaughlin, Timothy. 2018, How WhatsApp Fuels Fake News and Violence in India, Retrieved from: https://www.wired.com/story/how-whatsapp-fuels-fake-news-and-violencein-india/

Parashar, Utpal. (05/042020). Arunachal Pradesh Officer Commits Suicide; COVID-19 Related Stress could be Trigger: Police, Retrieved from: https://www.hindustantimes.com/india-news/arunachal-pradesh-officer-commits-suicidecovid-19-related-stress-could-be-trigger-police/

Pellman Rowland, Michael. 17/12/2017, Demand for Meat Is Growing Rapidly in India. This Could Impact All of Us, Forbes, Accessed From: https://www.forbes.com/sites/michaelpellmanrowland/2017/12/17/india-meatincrease/\#137dd8bb33b1

Parija, Pratik, (28/02/2020). Indian Poultry Sales Drop on Virus Rumors Spread by Social Media, Bloomberg, Accessed from: https://www.bloomberg.com/news/articles/2020-0227/rumors-of-avian-links-to-coronavirus-hit-poultry-sales-in-india

Sunstein, Cass. R. 2009, On Rumors: How Falsehoods Spread, Why We Believe Them, What Can Be Done, The Washington Post, Retrieved from: https://www.washingtonpost.com/wpsrv/style/longterm/books/chap1/onrumors.htm

Sivapriyan, ETB. (2020, 03, 18), Poultry industry in Tamil Nadu worst-hit due to coronavirus and avian flu, Deccan Herald, Accessed from:

https://www.deccanherald.com/national/south/poultry-industry-in-tamil-nadu-worst-hit-dueto-coronavirus-and-avian-flu-814975.html

Times of India, (20/03/2020), Coronavirus: Is it safe to eat meat and poultry? Accessed from: https://timesofindia.indiatimes.com/life-style/health-fitness/diet/coronavirus-is-it-safe-to-eatmeat-and-poultry 


\section{Sanrachna}

The Wire, (21/03/2020). Chicken and the New Coronavirus - No, They Are Not Related, Retrieved from: https://science.thewire.in/the-sciences/coronavirus-covid-19-chickenbetacoronavirus-ibv/

The Wire. (16/04/2020), Coronavirus Lockdown: As Hunger Grows, the Fear of Starvation Is Real, Accessed from: https://thewire.in/rights/covid-19-100-million-hunger-pds-universal

W. Goddard, Andrew, 2017, The Neurobiology of Panic: A Chronic Stress Disorder, Sage Publication, Vol 1, pp. 1-14. 